\title{
Selenite Reduction and the Biogenesis of Selenium Nanoparticles by Alcaligenes faecalis Se03 Isolated from the Gut of Monochamus alternatus (Coleoptera: Cerambycidae)
}

\author{
Yuting Wang ${ }^{1,2,3}$, Xian Shu ${ }^{1,2}$, Qing Zhou ${ }^{1,2}$, Tao Fan ${ }^{3}$, Taichu Wang ${ }^{3}$, Xue Chen ${ }^{1,2}$, \\ Minghao $\mathrm{Li}^{1,2,4}$, Yuhan $\mathrm{Ma}^{1,4}$, Jun $\mathrm{Ni}^{1,4}{ }^{1}$, Jinyan Hou ${ }^{1,4}$, Weiwei Zhao ${ }^{1}$, Ruixue $\mathrm{Li}^{3}$, \\ Shengwei Huang $1,4, *(1)$ and Lifang $\mathrm{Wu}^{1,3,4, *}$ \\ 1 Key Laboratory of High Magnetic Field and Ion Beam Physical Biology, Hefei Institutes of Physical Science, \\ Chinese Academy of Sciences, Hefei 230031, China; wangyuting2006@outlook.com (Y.W.); \\ sx360775419@gmail.com (X.S.); USTCzq1@outlook.com (Q.Z.); chenxueahau@163.com (X.C.); \\ limh@ipp.ac.cn (M.L.); yuhanmie@ipp.ac.cn (Y.M.); nijun@ipp.ac.cn (J.N.); jyhou@ipp.ac.cn (J.H.); \\ annyzhao@ipp.ac.cn (W.Z.) \\ 2 School of Life Sciences, University of Science and Technology of China, Hefei 230026, China \\ 3 The Sericultural Research Institute, Anhui Academy of Agricultural Science, Hefei 230061, China; \\ fantao1116@sohu.com (T.F.); wangtaichu@eyou.com (T.W.); li-ruixue@163.com (R.L.) \\ 4 Key Laboratory of Environmental Toxicology and Pollution Control Technology of Anhui Province, \\ Hefei Institutes of Physical Science, Chinese Academy of Sciences, Hefei 230031, China \\ * Correspondence: swhuang@ipp.ac.cn (S.H.); lfwu@ipp.ac.cn (L.W.); Tel.: +86-0551-6559-5672 (S.H.); \\ +86-0551-6559-1413 (L.W.)
}

Received: 23 August 2018; Accepted: 14 September 2018; Published: 17 September 2018

\begin{abstract}
In this study, a bacterial strain exhibiting high selenite $\left(\mathrm{Na}_{2} \mathrm{SeO}_{3}\right)$ tolerance and reduction capacity was isolated from the gut of Monochamus alternatus larvae and identified as Alcaligenes faecalis Se03. The isolate exhibited extreme tolerance to selenite (up to $120 \mathrm{mM}$ ) when grown aerobically. In the liquid culture medium, it was capable of reducing nearly $100 \%$ of 1.0 and $5.0 \mathrm{mM} \mathrm{Na}_{2} \mathrm{SeO}_{3}$ within 24 and $42 \mathrm{~h}$, respectively, leading to the formation of selenium nanoparticles (SeNPs). Electron microscopy and energy dispersive X-ray analysis demonstrated that A. faecalis Se03 produced spherical electron-dense SeNPs with an average hydrodynamic diameter of $273.8 \pm 16.9 \mathrm{~nm}$, localized mainly in the extracellular space. In vitro selenite reduction activity and real-time PCR indicated that proteins such as sulfite reductase and thioredoxin reductase present in the cytoplasm were likely to be involved in selenite reduction and the SeNPs synthesis process in the presence of NADPH or NADH as electron donors. Finally, using Fourier transform infrared spectroscopy, protein and carbohydrate residues were detected on the surface of the biogenic SeNPs. Based on these observations, $A$. faecalis Se03 has the potential to be an eco-friendly candidate for the bioremediation of selenium-contaminated soil/water and a bacterial catalyst for the biogenesis of SeNPs.
\end{abstract}

Keywords: selenite reduction; Alcaligenes faecalis; biogenic selenium nanoparticles; electron microscopy analysis; real-time PCR

\section{Introduction}

Selenium (Se) is a naturally occurring chalcogen element that possesses both metallic and nonmetallic properties [1]. It is an essential micronutrient for both prokaryotes and eukaryotes at low concentrations, but it can be toxic to organisms at higher levels [2]. For example, Se can act as an antioxidant and protect against the cellular damage caused by oxygen radicals; however, 
an overdose of Se can disrupt the integrity of proteins and decrease cellular enzymatic activity, resulting in chronic or acute selenosis [3,4]. Se exists in nature in multiple organic and inorganic forms, two of which there are mobile, water-soluble, bioavailable and toxic: selenite $\left(\mathrm{SeO}_{3}{ }^{2-}\right)$ and selenate $\left(\mathrm{SeO}_{4}{ }^{2-}\right)$. While selenite is generally more toxic than selenate, both can be easily absorbed by plants and animals from Se-rich soil or water containing Se, thus entering the food chain and posing a potential threat to animals and humans $[5,6]$. Thus, Se is of significant research interest in terms of environmental protection and public health.

Compared with selenite and selenate, elemental selenium $\left(\mathrm{Se}^{0}\right)$ is insoluble and shows little or no toxicity in terrestrial and aquatic environments. Therefore, the reduction of both selenate and selenite to $\mathrm{Se}^{0}$ has been identified as an ideal strategy for selenium detoxification and Se recovery in contaminated water, soil, and industrial effluent [7]. While various physicochemical and biological methods have been applied to reduce selenate and selenite into $\mathrm{Se}^{0}$ [8-10], biological approaches are generally preferred due to additional benefits such as their low cost, eco-friendly nature, and ability to employ self-generating catalysts [4]. Microorganisms thus play a crucial role in the transformation of selenite and selenate via metabolic reactions, and a variety of microorganisms, including Duganella sp. [3], Agrobacterium. sp. [3], Enterobacter cloacae [11], Vibrio natriegens [12], Pseudomonas putida [13], Bacillus cereus [14], Bacillus mycoides [15], and Shewanella oneidensis [16], have been reported to have reducing ability. For example, Yee et al. [11] reported that $\mathrm{Se}(\mathrm{VI})$ reduction and the precipitation of $\mathrm{Se}^{0}$ by facultative anaerobes $E$. cloacaea are regulated by oxygen-sensing transcription factors (such as fumarate nitrate reduction regulators) and occur under suboxic conditions. Avendaño et al. [13] found that P. putida KT2440 is able to reduce selenite (but not selenate) aerobically to Se nanoparticles (SeNPs), with the synthesized SeNPs located in the surrounding medium or bound to the cell membrane. In addition, research on the accumulation and metabolism of selenium in Saccharomyces cerevisiae also showed that yeast cells can convert selenite and selenate to selenoamino acids, in particular selenomethionine, and can accumulate up to $3000 \mu \mathrm{g} \cdot \mathrm{g}{ }^{-1}$ of selenium [17]. The presence of $\mathrm{Se}^{0}$ in yeast cell structures was also reported by Jiménez-Lamana et al. [18].

It is interesting to note that a number of these microbes can biosynthesize SeNPs of a defined size and shape in the selenite/selenate reduction process $[11,13,19]$. Compared to physicochemical methods, the biosynthesis of SeNPs has several advantages, such as specificity, safety, stability, and an eco-friendly nature [20], in addition to specific spectral and optical properties [21,22] and antimicrobial and anticancer activity [23-25]. Because of this, the microbial biosynthesis of SeNPs has great potential for use in selenium bioremediation and nanobiotechnology.

In this work, we studied the reduction of selenite and the biosynthesis of SeNPs by the bacterium Alcaligenes faecalis Se03, which was isolated from the gut of the larvae of the herbivorous insect Monochamus alternatus (Coleoptera: Cerambycidae). A. faecalis is an aerobic $\beta$-proteobacterium commonly found in the environment that exhibits heterotrophic nitrification and aerobic denitrification abilities [26]. Genome mining in A. faecalis has also demonstrated that its central metabolism is equipped with enzymes necessary to produce a high yield of reducing power (i.e., $\mathrm{NAD}(\mathrm{P}) \mathrm{H}$ equivalents) [27]. This ability is useful for selenite bioremediation, meaning A. faecalis is an attractive bacterial candidate for applications related to this biocatalytic process.

\section{Results and Discussion}

\subsection{Isolation, Characterization, and Identification of Bacterial Strains}

In previous research, several species of selenite-reducing bacteria, such as Streptomyces sp. [28], Stenotrophomonas maltophilia [29], and Burkholderia fungorum [10], have been isolated from the soil or rhizosphere. However, few bacterial species have been isolated from insects. Insects harbor large gut communities of specialized bacteria because their gut presents a unique environment for microbial colonization [30]. In this study, 13 bacterial strains were isolated from gut samples of M. alternatus using yeast extract peptone (YEP) plates supplemented with $10 \mathrm{mM}$ sodium selenite, suggesting that the insect gut could be a new source of microorganisms capable of transforming selenite into elemental 
selenium $\left(\mathrm{Se}^{0}\right)$. Of the 13 strains, isolate \#03 exhibited good growth and the ability to reduce selenite to red $\mathrm{Se}^{0}$ (Figure 1). Therefore, this isolate (named Se03) was chosen for further study.

Based on 16S rRNA gene sequence and phylogenetic evolution analysis, isolate Se03 showed a high degree of similarity (99\%) with Alcaligenes faecalis (Figure 2). Given that it also exhibited the typical biochemical and physiological characteristics of $A$. faecalis (Table 1), the strain Se03 was identified as A. faecalis Se03. A. faecalis is a Gram-negative, rod-shaped bacterium that is commonly found in soil, water, and environments associated with animals. In addition, it has been recently demonstrated that $A$. faecalis can degrade a wide range of aromatic compounds including polyaromatic hydrocarbon [27], naphthalene, and phenanthrene [31], and can detoxify heavy metals [32,33]. However, this is the first study to demonstrate that an A. faecalis strain can reduce selenite to $\mathrm{Se}^{0}$ and biosynthesize SeNPs.

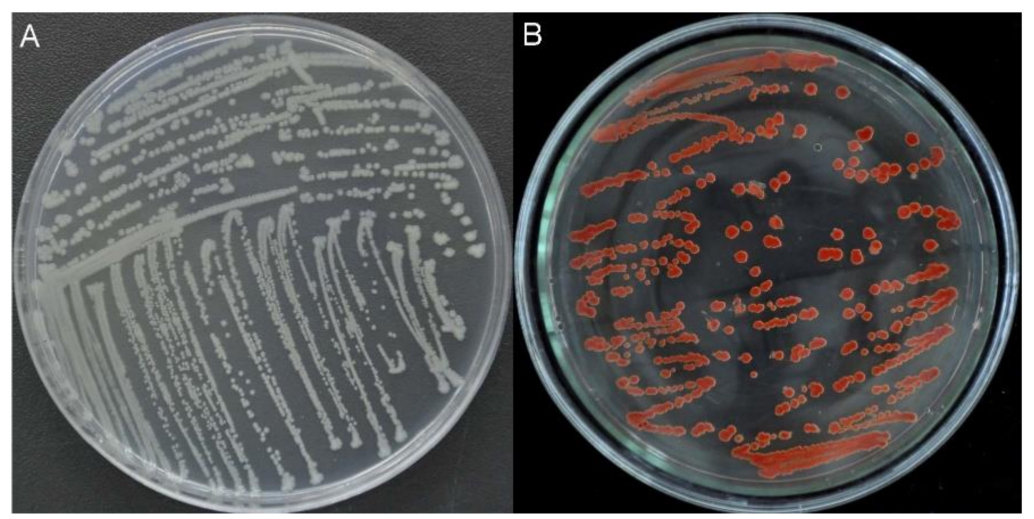

Figure 1. Growth of strain Se03 on YEP (Yeast Extract Peptone) agar plates in absence (A) and presence (B) of $5.0 \mathrm{mM}$ selenite. The red colony color indicates selenite reduction and the formation of elemental selenium $\left(\mathrm{Se}^{0}\right)$.

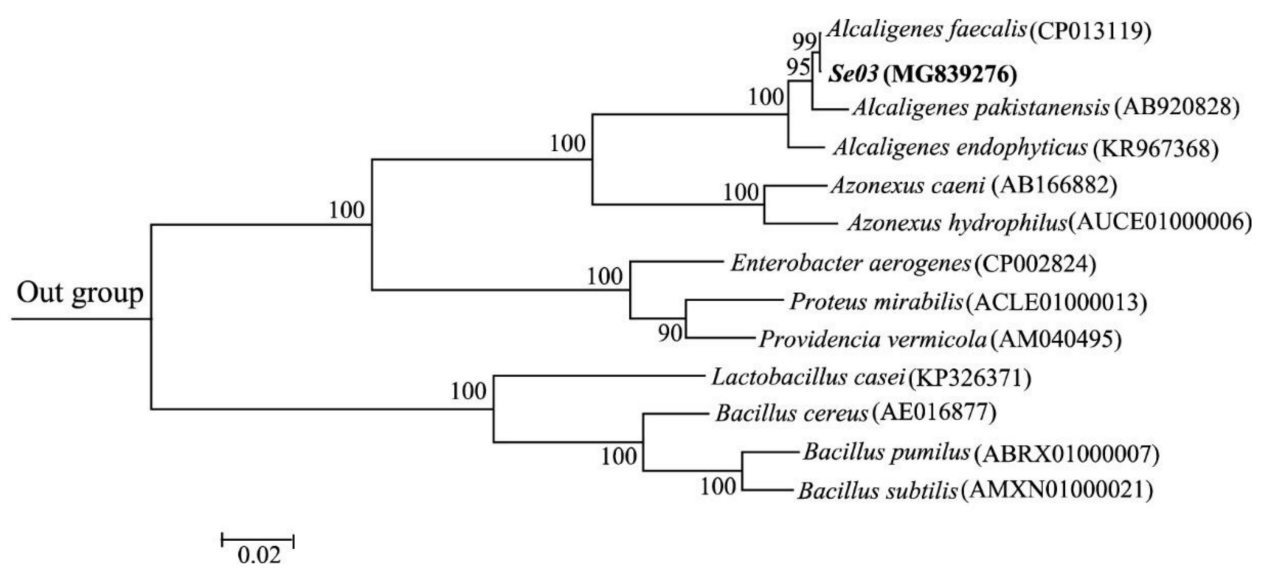

Figure 2. Maximum likelihood tree based on the $16 \mathrm{~S}$ rRNA gene sequence of isolate Se03 and the sequences of representative strains from GenBank. The scale bars indicate 0.02 substitutions per site. Sphingobacterium zeae (KU201960) was used as an outgroup. 
Table 1. Physiological and biochemical characteristic of the bacterial isolate Se03.

\begin{tabular}{cccc}
\hline Characteristic & Result & Characteristic & Result \\
\hline Gram-staining & - & Assimilation of & \\
Nitrite reduction & + & Glycine & - \\
Motility & + & Lactose & + \\
Oxidase & + & Maltose & + \\
Catalase & + & D-fructose & + \\
Indole test & - & D-Raffinose & + \\
Nitrate reduction & + & Cellobiose & + \\
Urease & + & Rhamnose & + \\
Hydrolysis of & & Sucrose & + \\
Starch & - & D-xylose & - \\
Casein & - & Arginine & + \\
Gelatin & - & Growth in $5 \% \mathrm{NaCl}$ & - \\
Growth at $5{ }^{\circ} \mathrm{C}$ & + & Growth in $10 \%$ & - \\
Growth at $42^{\circ} \mathrm{C}$ & + & NaCl & \\
\hline
\end{tabular}

Growth/Posetive result(+), No growth/Negtive result(-).

\subsection{Selenite Reduction and the Formation of Elemental Selenium}

To determine the selenite tolerance of the Se03 isolate, bacterial cells were grown in YEP medium with different concentrations of selenite $(0-300 \mathrm{mM})$. Minimum inhibitory concentration (MIC) assays demonstrated that strain Se03 had an extremely high tolerance to selenite; it was able to grow and produce $\mathrm{Se}^{0}$ in the presence of selenite concentrations of up to $120 \mathrm{mM}$. This indicates that $A$. faecalis Se03 has a higher level of resistance to selenite than that reported for some other bacteria such as Burkholderia fungorum (5 mM) [10] and Azoarcus sp. CIB (8 mM) [19], and it is similar to other highly selenite-tolerant strains, including Vibrio natriegens (100 mM) [12] and Pseudomonas moraviensis (120 mM) [34].

The selenite reduction ability of $A$. faecalis Se03 was evaluated using liquid YEP medium supplemented with 1.0 and $5.0 \mathrm{mM} \mathrm{Na}_{2} \mathrm{SeO}_{3}$ (Figure 3). The Shapiro-Wilk test showed a normal distribution for all selenite reduction and $\mathrm{Se}^{0}$ formation data (Supplementary Table S1). Depletion of $\mathrm{SeO}_{3}{ }^{2-}$ was observed within 6 hours at $\mathrm{SeO}_{3}{ }^{2-}$ concentrations of 1.0 and $5.0 \mathrm{mM}$, though only $5.0 \%$ and $1.8 \%$ of the $\mathrm{SeO}_{3}{ }^{2-}$ had been reduced at this stage, respectively. $\mathrm{SeO}_{3}{ }^{2-}$ reduction and $\mathrm{Se}^{0}$ formation by $\mathrm{Se} 3 \mathrm{3}$ appeared to be a continuous process that was associated with this strain's growth kinetics. In the bacterial cultures with an initial selenite concentration of $1.0 \mathrm{mM}$, most of the selenite $(>90 \%)$ was exhausted during exponential growth phase (between 12 and $24 \mathrm{~h}$ ) and then completely reduced after $36 \mathrm{~h}$ of incubation (Figure $3 \mathrm{~A}$ ). In contrast, the reduction behavior of $A$. faecalis Se03 changed when cultured in a YEP medium with $5 \mathrm{mM}$ selenite. Selenite reduction occurred at the very end of the exponential growth phase and well into the stationary phase. During the exponential phase, only $10 \%$ of the initial selenite was reduced, while the remaining selenite was depleted during the stationary phase (Figure 3B). These findings are similar to those of Lampis et al. [29], who showed that $\mathrm{SeO}_{3}{ }^{2-}$ reduction and $\mathrm{Se}^{0}$ formation were associated with the growth kinetics of $S$. maltophilia SeITE02. When selenite was added to the culture medium at a low concentration (0.5 $\mathrm{mM})$, it was $100 \%$ depleted within an incubation period of $52 \mathrm{~h}$ (i.e., during the exponential phase). However, when supplemented with $2.0 \mathrm{mM}$ selenite, less than $10 \%$ of the $\mathrm{SeO}_{3}{ }^{2-}$ had been reduced after $52 \mathrm{~h}$ of incubation, while $86 \%$ of the initial selenite was reduced after $192 \mathrm{~h}$ of incubation (i.e., during the stationary phase). A similar pattern was also discovered by Khoei et al. [10], who found that about 75\% of initial $\mathrm{SeO}_{3}{ }^{2-}$ depletion occurred during the exponential growth phase when Burkholderia fungorum 95 was cultured with $0.5 \mathrm{mM}$ selenite. However, in the presence of $2.0 \mathrm{mM} \mathrm{SeO}_{3}{ }^{2-}$, only $10 \%$ of the $\mathrm{SeO}_{3}{ }^{2-}$ was depleted during the first $24 \mathrm{~h}$, with the majority of the reduction occurring during 
the stationary growth phase (between 24 and $48 \mathrm{~h}$ ). In addition to this, it has been reported that Bacillus mycoides SeITE01 is able to reduce most of the $\mathrm{SeO}_{3}{ }^{2-}$ during the exponential phase at a $\mathrm{SeO}_{3}{ }^{2-}$ concentration of $0.5 \mathrm{mM}$. However, at a concentration of $2 \mathrm{mM}$, only $25 \%$ of the $\mathrm{SeO}_{3}{ }^{2-}$ was reduced during the exponential growth stage, with the remaining $\mathrm{SeO}_{3}{ }^{2-}$ depleted during the stationary phase [15]. Therefore, it seems clear that, for $A$. faecalis Se03, the selenite reduction rate and efficiency are most likely related to the initial selenite concentration and/or the bacterial growth phase. It is also possible that selenite reduction is mediated by cellular reductases and/or reducing compounds whose production and consumption are linked to the growth phase of the microbe [29].

Furthermore, it is quite generally believed that elemental selenium is endowed with a characteristic red color. In this study, the reduction and consequent depletion of $\mathrm{SeO}_{3}{ }^{2-}$ led to the culture medium turning bright red, indicating the presence of $\mathrm{Se}^{0}$, which is generally associated with this color. No color change was observed in the two control flasks, one containing only selenite and the other containing only the bacterial strain, suggesting that $A$. faecalis $\mathrm{Se} 03$ plays a role in selenite reduction and $\mathrm{Se}^{0}$ formation. About $90 \%$ of the reduced selenite was transformed into $\mathrm{Se}^{0}$ at both concentrations tested, although the $\mathrm{SeO}_{3}{ }^{2-}$ concentration of $5.0 \mathrm{mM}$ required a significantly longer period of time (Figure 3B). It should be noted that a delay in the formation of $\mathrm{Se}^{0}$ following $\mathrm{SeO}_{3}{ }^{2-}$ reduction was observed, with the bacterial cultures turning light red after 12 and $18 \mathrm{~h}$ of incubation at concentrations of 1.0 and $5.0 \mathrm{mM} \mathrm{SeO}_{3}{ }^{2-}$, respectively (Figure 3). These results are in good agreement with the $\mathrm{Se}^{0}$ levels in bacterial cultures measured using a spectrophotometer in this study. For example, at a concentration of $1.0 \mathrm{mM} \mathrm{SeO}_{3}{ }^{2-}, 11 \%$ of the initial selenite was reduced after $12 \mathrm{~h}$ of incubation, but only $5.1 \%$ was transformed into detectable $\mathrm{Se}^{0}$. The delay in the formation of $\mathrm{Se}^{0}$ has also been reported by Lampis et al. [15] and Fernández-Llamosas et al. [12]. It is assumed to be caused by the formation of metabolic intermediates such as RSeR prior to $\mathrm{Se}^{0}$ formation $[29,35]$. However, past research on SeNPs synthesized via microorganism activity has mostly focused on bacteria or fungi, while $\mathrm{Se}^{0}$ has rarely been detected and quantified in the presence of yeast. Kieliszek et al. [17] reported that yeast cells have the ability to reduce selenite(IV) ions to $\mathrm{Se}^{0}$ in the presence of sulphate(IV) ions. Jiménez-lamana et al. [18] also verified the presence of inorganic nanoparticulate selenium in Se-rich yeast Saccharomyces cerevisiae firstly by using single particle inductively coupled plasma mass spectrometry (ICPMS) and suggested that this species should be included in the speciation scheme for this element in Se-rich yeasts.
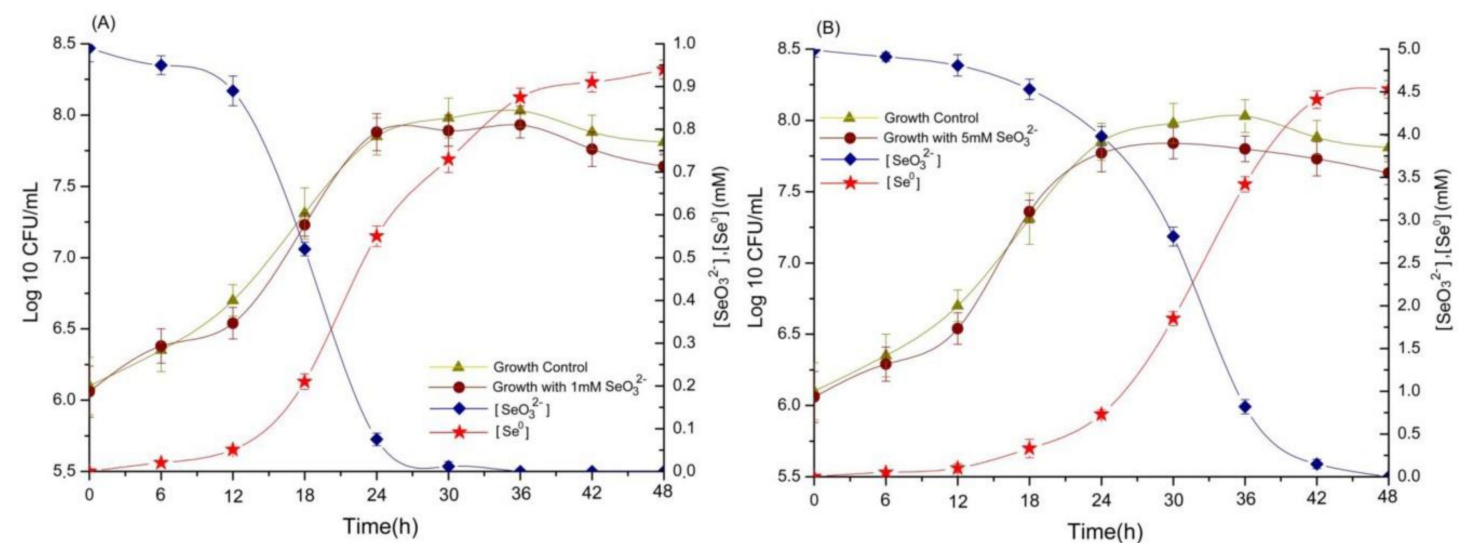

Figure 3. Time courses of bacterial growth, $\mathrm{SeO}_{3}{ }^{2-}$ reduction, and $\mathrm{Se}^{0}$ formation by the strain A. faecalis Se03 grown in YEP medium supplied with (A) $1 \mathrm{mM} \mathrm{Na}_{2} \mathrm{SeO}_{3}$, and (B) $5.0 \mathrm{mM} \mathrm{Na} 2 \mathrm{SeO}_{3}$. Each test was performed in triplicate and error bars represent the standard deviation.

\subsection{Location of SeNPs within Cell Cultures of A. faecalis SeO3}

Transmission electron microscopy (TEM) and scanning electron microscopy (SEM) were used to determine the location of SeNPs produced by A. faecalis Se03. TEM analysis found that most of the electron-dense nanoparticles were located in the extracellular spaces and only a few were observed in the cytoplasm (Figure $4 \mathrm{~B}, \mathrm{C}$ ), while these particles were not detected in cell cultures in the absence of $\mathrm{SeO}_{3}{ }^{2-}$ (Figure 4A). The particles were spherical and of various sizes (i.e., diameters ranging from approximately 
100 to $400 \mathrm{~nm}$ ), similar to those found in in Duganella sp. [3], Agrobacterium sp. [3], E. cloaocae [11], B. selenitireducens [20]. SEM micrographs also showed the extracellular location of the electron-dense nanoparticles, their spherical shape, and various sizes (Figure 5, indicated by white arrows). Interestingly, empty ghost cells were observed using TEM (indicated by the red arrows in Figure 4B). Empty ghost cells were also found in a study of Candida utilis ATCC 9950. These ghost cells were observed in aging yeast as a result of cell membrane breakage and cytoplasm leakage when C utilis ATCC 9950 was cultured in media supplemented with sodium selenite [36]. Lampis et al. [29] also found that empty cells were abundant during the stationary growth phase of $S$. maltophilia SeITE02 in the presence of $0.5 \mathrm{mM}$ selenite, possibly due to the release of $\mathrm{Se}^{0}$ particles into the medium. However, there is a lack of experimental evidence to determine whether vesicular secretion or cell lysis is involved in the release of intracellularly formed $\mathrm{Se}^{0}$ nanoparticles by A. faecalis Se03. More research is thus needed to further elucidate the release mechanisms of $\mathrm{Se}^{0}$ nanoparticles.

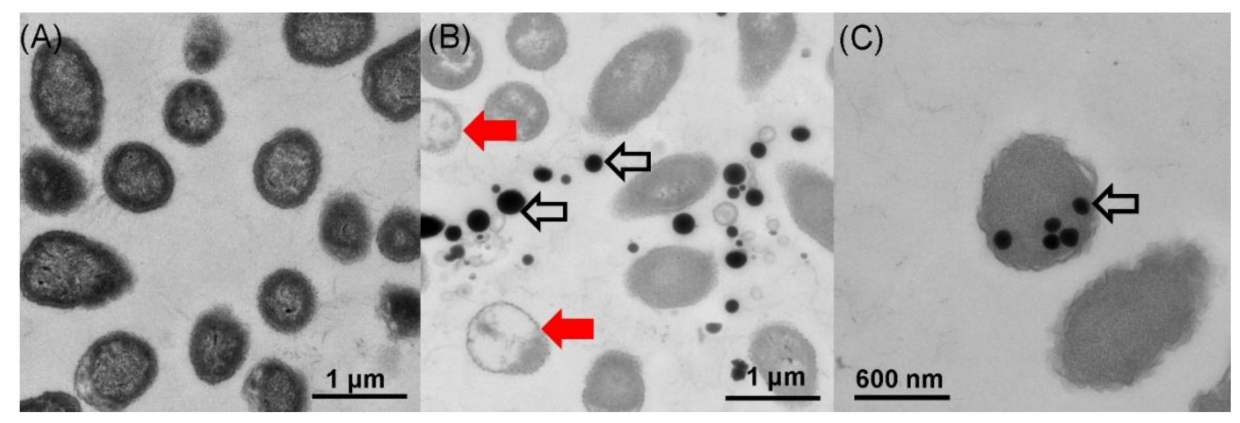

Figure 4. TEM images of $A$. faecalis Se03 in (A) the absence and $(\mathbf{B}, \mathbf{C})$ presence of $5 \mathrm{mM}$ selenite after $36 \mathrm{~h}$ incubation. Electron-dense nanoparticles (white arrows) located extracellularly (B) or intracellularly (C). Red arrows indicate "empty ghost" cells.

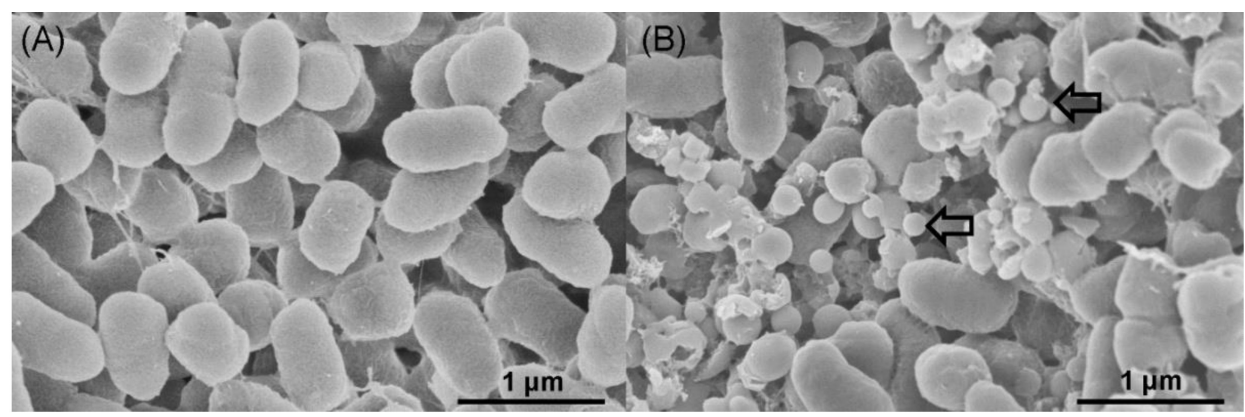

Figure 5. SEM micrographs of A. faecalis Se03 cultures grown in (A) absence and (B) presence of $5.0 \mathrm{mM}$ selenite after $36 \mathrm{~h}$ incubation. Electron-dense nanoparticles (white arrows) located extracellularly.

\subsection{Characterization of SeNPs Produced by A. faecalis SeO3}

\subsubsection{DLS Analyses and SEM-EDX}

Results of the dynamic light scattering (DLS) analysis of the purified SeNPs are presented in Figure 6. It was revealed that the average diameter of the nanoparticles recovered after $36 \mathrm{~h}$ of incubation was $273.8 \pm 16.9 \mathrm{~nm}$, similar to that found in Pseudomonas putida (266 nm) [13], and Bacillus selenitireducens $(200 \mathrm{~nm})$ [37]. Bioproduced SeNPs of various sizes have been described in Vibrio natriegens (136 $\pm 31 \mathrm{~nm})$ [12], Azoarcus sp. CIB (174 $\pm 36 \mathrm{~nm}$ in aerobic cultures and $90 \pm 26 \mathrm{~nm}$ in anaerobic cultures) [18], and Bacillus mycoides SeITE01 (50 to $400 \mathrm{~nm}$ ). Energy-dispersive X-ray (EDX) analysis showed that the purified SeNPs were spherical and clearly indicated the presence of selenium, with specific absorption peaks observed at $1.37,11.22$, and $12.49 \mathrm{keV}$. 


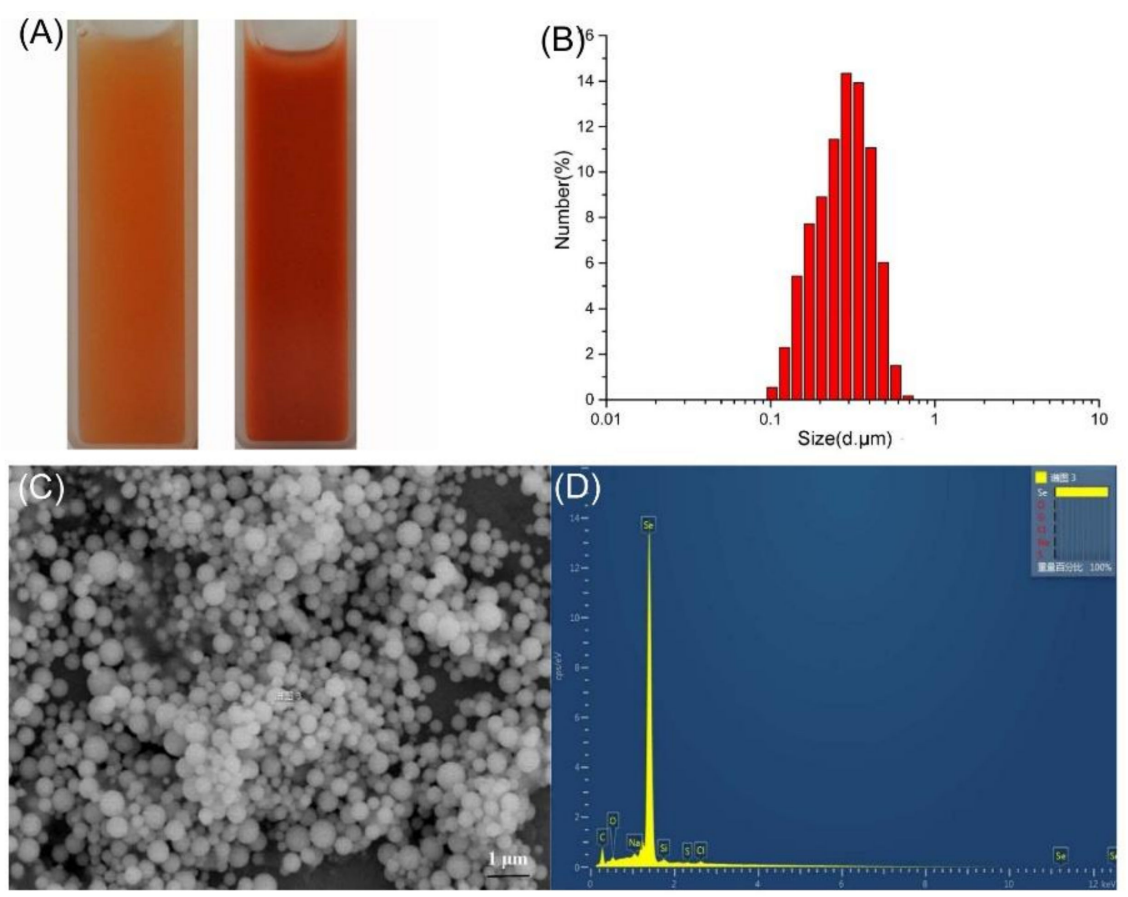

Figure 6. DLS spectra of purified SeNPs produced by A. faecalis Se03 in YEP supplemented with $5.0 \mathrm{mM}$ selenite. (A) Selenite-dosing cells (left) and purified nano-selenium (right); (B) size distribution of purified SeNPs; (C) SEM micrographs of purified SeNPs. (D) EDX analysis of purified SeNPs showing its selenium composition.

\subsubsection{FTIR Analysis}

The Fourier transform infrared (FTIR) spectrum of the SeNPs is presented in Figure 7. The bands observed at $3270 \mathrm{~cm}^{-1}, 3184 \mathrm{~cm}^{-1}$, and at $3070 \mathrm{~cm}^{-1}$ may be assigned to different $\mathrm{N}-\mathrm{H}$ stretching vibrations and amide $\mathrm{A}$ of proteins, respectively. A number of typical $\mathrm{C}-\mathrm{H}$ stretching bands can also be observed at 2955, 2923, 2872, and $2850 \mathrm{~cm}^{-1}$ (aliphatic groups). The band at $1660 \mathrm{~cm}^{-1}$ with the accompanying less-intensive bands at 1528 and $1230 \mathrm{~cm}^{-1}$ represent the amide I, amide II, and amide III modes, respectively, typical of proteins. The weaker band at $1456 \mathrm{~cm}^{-1}$ corresponds to the $\mathrm{CH}_{2}$ scissoring mode. Note that the band at $1400 \mathrm{~cm}^{-1}$ may be assigned to the symmetric stretching vibrations of carboxylate $\left(\mathrm{COO}^{-}\right)$, while its asymmetric counterpart may be seen as a peak around $1620 \mathrm{~cm}^{-1}$ (largely overlapped by the amide I band). The bands at 1164 and $1070 \mathrm{~cm}^{-1}$ are typical of $\mathrm{C}-\mathrm{O}-\mathrm{C}$ and $\mathrm{C}-\mathrm{O}$ vibrations in carbohydrates, which may represent the presence of polysaccharides in the capping layer of the SeNPs. Thus, the FTIR analysis clearly demonstrated that organic residues such as carbohydrates and proteins were present on the surface of the SeNPs produced by A. faecalis Se03. Previous studies on Thauera selenatis [38] and S. maltophilia SeITE02 [29] have identified the functional groups of the bacterial biomolecules involved in the selenite reduction and the stabilization (capping) process for synthesized SeNPs. Therefore, our findings not only indicate bacterial protein-mediated selenite reduction but also corroborate the synthesis and stabilization of SeNPs by the proteins present in the bacteria [38]. 


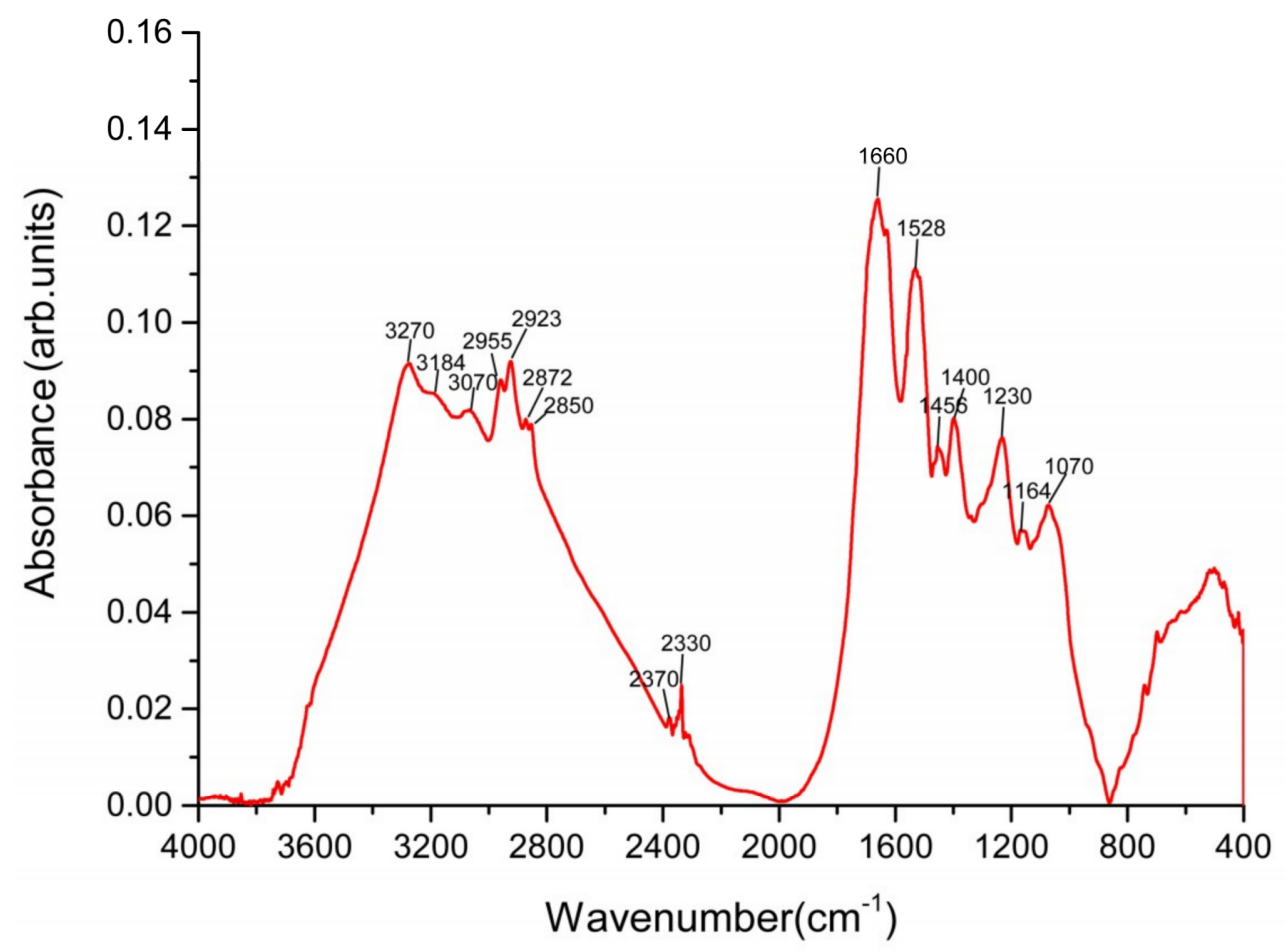

Figure 7. The FTIR spectrum of Bio-SeNPs registered in the $4000-400 \mathrm{~cm}^{-1}$ infrared regions.

\subsection{Biocatalytic Selenite Reduction Activity Assays}

To determine the mechanism of selenite reduction to Bio-SeNPs in A. faecalis Se03, the selenite reduction activity of different fractions of the cell culture were tested. Results presented in Figure 8 clearly demonstrated that selenite reduction activity in Se 03 cells is localized in the cytoplasmic fraction. Furthermore, selenite reduction by the cytoplasmic fraction is an enzymatic process since an electron donor (NADH or NADPH) is required for this reaction to take place. The observed involvement of enzymes in the reduction of selenite was also found in other microorganisms. Khoei et al. [10] found that cytoplasmic fractions of two Burkholderia fungorum strains (B. fungorum DBT1 and B. fungorum 95) exhibited selenite reduction activity in the presence of an electron donor (NADH or NADPH) while supernatant, exopolysaccharide (EPS) or membrane fraction possessed no activity for both strains. In addition, Lampis et al. [28] found that the selenite reduction activity of S. maltophilia SeITE02 cells was mainly attributed to the cytoplasmic fraction with NADH served as an electron donor. Thus, it is possible to infer that selenite that imported into the $A$. faecalis Se 03 cell was reduced and formed inside as small $\mathrm{Se}^{0}$ seeds in the cytoplasm by thioredoxin reductase [39], or NADH/NADPH related reductases [40]. Interestingly, selenium nanoparticles accumulated extracellularly to a noticeable extent after $36 \mathrm{~h}$ incubation as shown in TEM micrograph (Figure 4B), suggesting the SeNPs formed inside the cell could be released into the extracellular space through certain export mechanism. Several systems exist in Gram-negative bacteria for SeNPs secretion out of the cell including outer membrane vesiculation [41], membrane-associated efflux pumps [42]. In addition, cell lysis prior to secretion is also possible way out for $\mathrm{Se}^{0}$ particles formed inside the cytoplasm [43]. Despite vesicles produced by Gram-negative bacteria can expulse material located in the periplasmic space or cytoplasm, such vesicles are about 20-250 nm as suggested by Kulp and Kuehn [41]. However, most of the observed $\mathrm{Se}^{0}$ spheres (about 60\%) were larger than that size (Figure 6B), while Se nanoparticles were too large to be released from bacterial cells without rupturing the cell walls. More importantly, empty ghost cells as a symbol of cell membrane breaking and cytoplasm leakage were observed by TEM (indicated by red arrows in Figure 4B). Thus, the majority of extracellularly observed $\mathrm{Se}^{0}$ spheres were most likely intracellularly produced and subsequently released following cell lysis, as reported in other microorganisms such as anaerobic granular sludge [44], Duganella sp. and Agrobacterium sp. [3] 
and Desulfovibrio desulfuricans [45]. However, additional experiments should be performed to address both the nature of $\mathrm{Se}^{0}$ formation and the release mechanism of SeNPs produced by A. faecalis Se03.

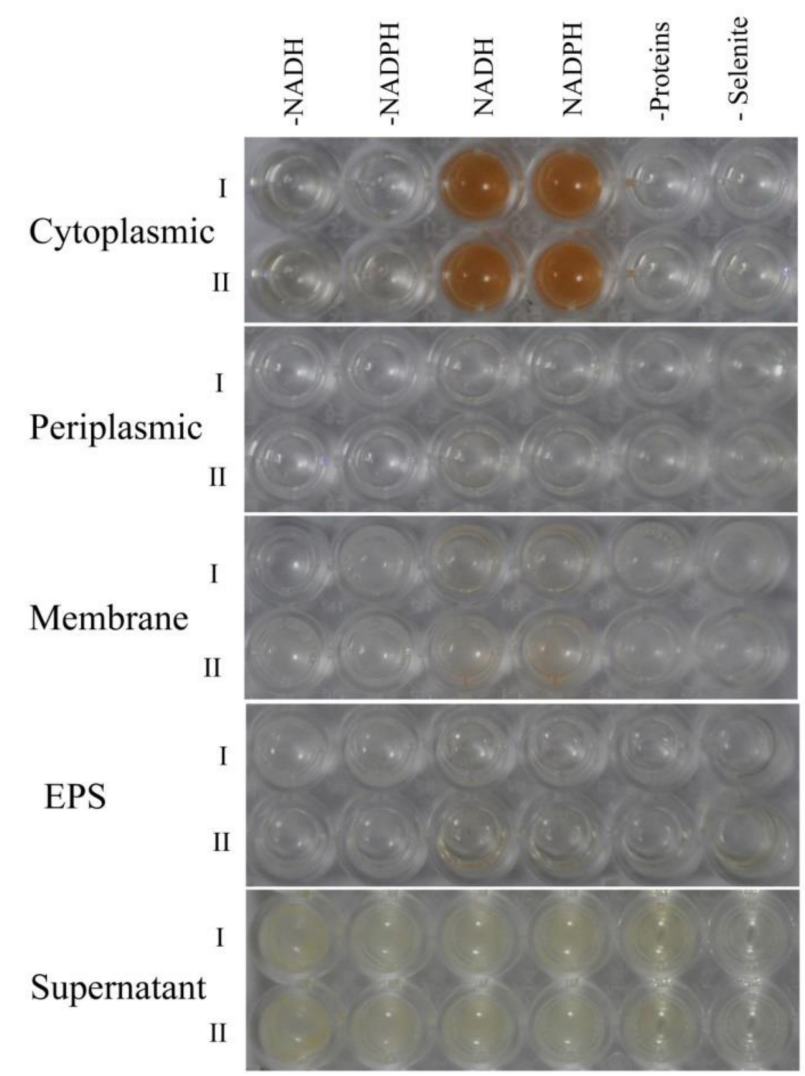

Figure 8. Selenite reduction assay on different subcellular fractions (cytoplasmic, periplasmic, and membrane), supernatant, and exopolysaccharide. All experiments were performed in duplicate (indicated by roman numbers), with addition of $5.0 \mathrm{mM} \mathrm{SeO}_{3}{ }^{2-}$ and $2.0 \mathrm{mM} \mathrm{NADH}$ or NADPH. While 3 following control negatives were performed: without protein fractions or supernatant or EPS, without selenite, without NADH or NADPH.

\subsection{Real-time PCR Analysis}

Previous studies have found that selenite can react with glutathione (GSH) to form $\mathrm{Se}^{0}$ and reduced GSH through Painter-type reactions [46] and that other enzymatic systems, such as sulfite reductase, flavoprotein, and thioredoxin, are also involved in the reduction of selenite and $\mathrm{Se}^{0}$ formation $[40,47]$. Therefore, the mRNA expression of genes suspected to be involved in selenite reduction and SeNP formation in A. faecalis $\mathrm{Se} 03$, including glutathione synthetase $(g s h \mathrm{~B})$, sulfite reductase (CysI), the sulfate transporter subunit (BV899_03375), flavoprotein sulfite reductase (BV899_18870), thioredoxin reductase (BV899_02360), peroxiredoxin (BV899_10955), and superoxide dismutase (BV899_06125), was assessed using real-time PCR (Table 2). The Shapiro-Wilk test showed a normal distribution of expression fold changes for all selected genes (Supplementary Table S1). As shown in Figure 9, the mRNA expression of $g s h$ B and BV899_18870 in cells cultured with selenite was not different from cells without selenite treatment, suggesting that GSH might not be involved in the reduction of selenite to SeNPs. However, selenite treatment significantly promoted the mRNA expression of CysI, BV899_03375, BV899_02360, BV899_10955, and BV899_06125 (a 4.4-, 2.2-, 4.7, 1.8-, and 9.6-fold increase, respectively).

Because the chemical and physical characteristics of $S$ and Se are very similar to each other, the enzymes involved in sulphate metabolism and in the trans-sulphuration pathway typically do not discriminate between $S$ and Se compounds [48]. Thus, selenate and selenite could be transported into cells via the sulfate transport system and reduced to $\mathrm{Se}^{0}$ in the cytoplasm $[49,50]$. Some bacteria are able to utilize selenite and selenate in their respiratory chain as electron acceptors, often along 
with sulphites and sulphates [47]. Harrison et al. [51] previously reported that the expression of sulfite reductase in Clostridium pasteurianum was induced by the presence of selenite and that it participated in selenite reduction in cells, while Kieliszek et al. [17] suggested that selenite(IV) reduction in yeast cells can be catalyzed by sulfate reductase using NADPH as a reducing agent. Furthermore, the thioredoxin system consisting of NADPH, thioredoxin reductase, and thioredoxin can reduce protein disulfides via redox-active dithiols, and it has been reported to be active in the in vitro reduction of selenite in Bacillus subtilis [52] and Pseudomonas seleniipraecipitans [1]. In addition, enzymes that are capable of scavenging reactive oxygen species (ROS), including peroxiredoxins and superoxide dismutase therefore, have been found to participate in the process of selenite reduction and $\mathrm{Se}^{0}$ formation and are induced by both selenate and selenite treatment under aerobic conditions [53,54].

Overall, this data suggests that $A$. faecalis Se03 may reduce selenite and produce $\mathrm{Se}^{0}$ via the action of reductases, such as sulfite reductase and thioredoxin reductase, instead of via GSH-mediated Painter-type reactions. However, it is likely that multiple mechanisms are involved in the reduction of selenite in the $A$. faecalis Se03 strain. Therefore, additional research based on proteomic analysis and mutant forms is necessary to identify the possible reduction mechanisms in A. faecalis Se03.

Table 2. Primers for targeting genes.

\begin{tabular}{|c|c|c|}
\hline Target Gene & Primer Sequence & Product Size (bp) \\
\hline Glutathione synthetase (A0A1Y1PZ31) & Forward: 5'-CCCAAAGTCGGGTTCGT-3' & \\
\hline Glutathione synthetase (AUA1Y IPZ31) & Reverse: 5'-CAAGTGCGTGGAATAGGAGTA-3' & 181 \\
\hline Sulfite reductase (A0A1Y1PQF9) & $\begin{array}{l}\text { Forward: 5'-TCAAGAGTGGGCTGACAAGA-3' } \\
\text { Reverse: } 5^{\prime} \text {-CACATCATTCAAGGGAGGC-3' }\end{array}$ & 186 \\
\hline Sulfate transporter subunit (A0A1Y1PY15) & $\begin{array}{l}\text { Forward: } 5^{\prime} \text {-CAAAGAGCAAACGGGTGA-3' } \\
\text { Reverse: } 5^{\prime} \text {-ACAATCGTGGAGGTGTAAGG-3' }\end{array}$ & 209 \\
\hline Flavoprotein sulfite reductase (A0A1Y1PQH1) & $\begin{array}{l}\text { Forward: } 5^{\prime} \text {-TTCCTGCCGCCCAATCTA-3' } \\
\text { Reverse: } 5^{\prime} \text {-TGCCTTCCAGCGACAACTC- } 3^{\prime}\end{array}$ & 161 \\
\hline Thioredoxin reductase (A0A1Y1PXH0) & $\begin{array}{l}\text { Forward: 5'-CAGGCTGCGGCGATTCAA-3' } \\
\text { Reverse: } 5^{\prime} \text {-TCTGGGCGTCCTCGGTCAA-3' }\end{array}$ & 249 \\
\hline Peroxiredoxin (A0A1Y1PUT6) & $\begin{array}{l}\text { Forward: } 5^{\prime} \text {-CATTGAAACCGCCACAGA- } 3^{\prime} \\
\text { Reverse: } 5^{\prime} \text {-CGCCCATTACGAAAGGAT- } 3^{\prime}\end{array}$ & 223 \\
\hline Superoxide dismutase (A0A1Y1PZA2) & $\begin{array}{l}\text { Forward: 5'-CCCGATGCCGATAGCACCCT-3' } \\
\text { Reverse: } 5^{\prime} \text {-ACTGAGCCAAGCCCAGCCAC-3' }\end{array}$ & 134 \\
\hline 16S r RNA & $\begin{array}{l}\text { Forward: } 5^{\prime} \text {-AGAGTTTGATCCTGGCTCAG-3' } \\
\text { Reverse: } 5^{\prime} \text {-CTGCTGCCTCCCGTAGGAGT-3' }\end{array}$ & 330 \\
\hline
\end{tabular}
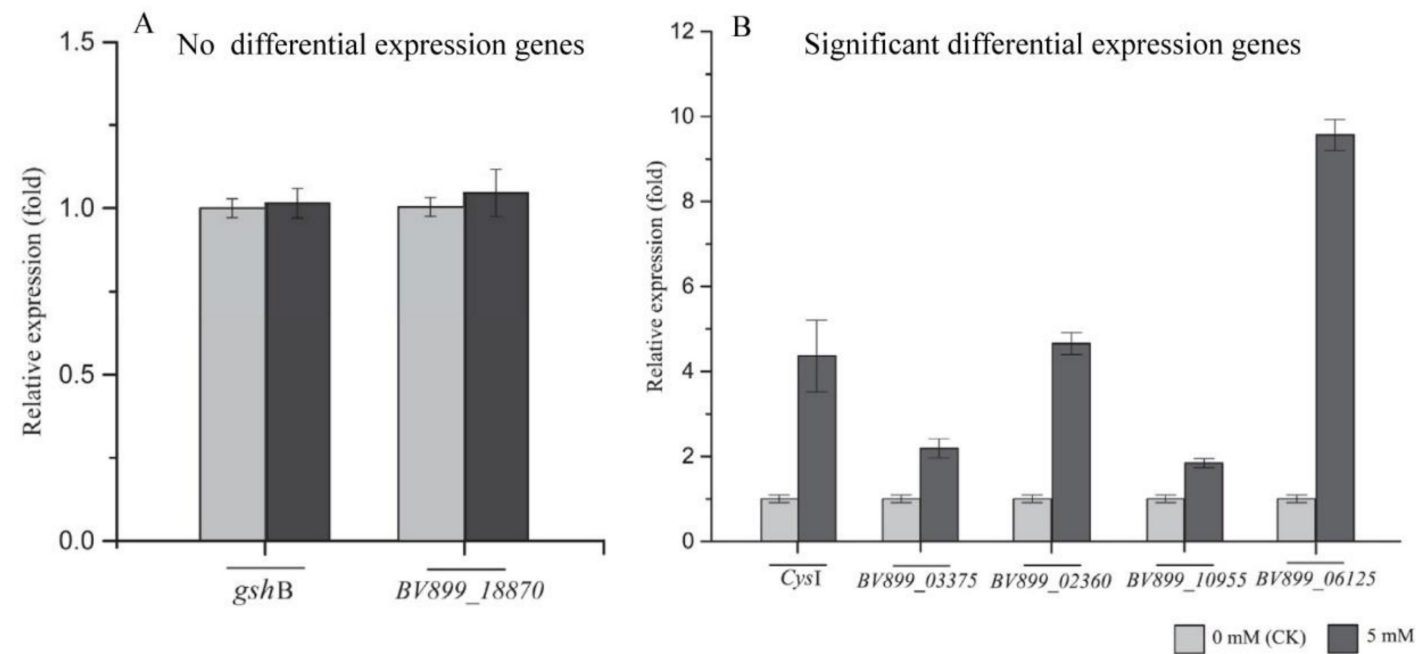

Figure 9. Real-time PCR results of expression levels of selected genes (A) Not significant differentially expressed genes, (B) significant differential expression of genes. Data are shown as fold changes by calculating expression levels of selenite treated samples compared to untreated (defined as 1). Data represent an average of three biological replicates \pm SD. 


\section{Materials and Methods}

\subsection{Chemicals and Culture Medium}

YEP broth was purchased from Qingdao Hopebio-Technology (Qingdao, China). Sodium selenite $\left(\mathrm{Na}_{2} \mathrm{SeO}_{3}, \geq 99 \%\right)$ was purchased from Sigma-Aldrich (St Louis, MO, USA) and diluted with distilled deionized water $\left(\mathrm{ddH}_{2} \mathrm{O}\right)$ to prepare a $\mathrm{Na}_{2} \mathrm{SeO}_{3}$ stock solution $(2 \mathrm{~mol} / \mathrm{L})$ and filter-sterilized. Aliquots of $\mathrm{Na}_{2} \mathrm{SeO}_{3}$ from the filter-sterilized stock solution were added to the YEP growth media when needed. All other analytical grade reagents were purchased from Sangon Biotech (Shanghai, China) and Sinopharm Chemical Reagent (Shanghai, China).

\subsection{Bacterial Isolation and Identification}

The third larval stage of the herbivorous insect M. alternatus (Coleoptera: Cerambycidae) was collected from Pinus massoniana growing in the seleniferous soils of Nanyang Forest Farm, Chizhou, Anhui Province, China. After returning to the laboratory, the larvae were dissected immediately and the gut extracts were pooled and homogenized as described by Huang et al. [55]. Briefly, 1 gram of a homogenized gut sample was serially diluted with sterilized distilled water by a factor of $10^{1}-10^{9}$. Aliquots $(100 \mu \mathrm{L})$ of each dilution were spread on YEP plates containing $10 \mathrm{mM}$ sodium selenite and incubated for $2-3$ days at $30{ }^{\circ} \mathrm{C}$ until visible colonies appeared on the plates. A red colony indicated selenite reduction. Individual colonies were streaked on new media to obtain pure bacterial monocultures. Of these monocultures, isolate \#03 (named Se03) was chosen for this study based on its apparent rate of growth and ability to reduce selenite to red elemental Se $\left(\mathrm{Se}^{0}\right)$.

The biochemical and physiological analysis of the Se03 isolate was conducted according to standard methods [56]. The 16S rRNA gene sequence of the Se03 isolate was amplified using bacterial universal primer 27F-1492R and sequenced as described by Huang et al. [55]. This 16S rRNA gene sequence was then compared with those found on the EzBioCloud server [57]. A phylogenetic tree was subsequently constructed with MEGA 7 using the maximum likelihood method [58]. The sequence was deposited in the GenBank database under the accession number MG839276.

\subsection{Selenite Sensitivity Tests}

In order to obtain the minimum inhibitory concentration (MIC) of $\mathrm{SeO}_{3}{ }^{2-}$, the $\mathrm{SeO}$ isolate was precultured in YEP medium at $30^{\circ} \mathrm{C}$ in a rotary shaker incubator $(180 \mathrm{rpm})$ for $18 \mathrm{~h}$ (the stationary growth phase). The cells were then harvested (centrifuge at $5000 \times g$ for $10 \mathrm{~min}$ ) and resuspended in fresh YEP medium. Finally, the cells were challenged $(1 \%, v / v)$ in a test tube containing $5 \mathrm{~mL}$ of fresh YEP medium to which various concentrations of $\mathrm{SeO}_{3}{ }^{2-}(0-300 \mathrm{mM})$ had been added. The first concentrations used were $0.5,1,3,5$ and $10 \mathrm{mmol} / \mathrm{L}$. Between 10 and $300 \mathrm{mmol} / \mathrm{L}$, the $\mathrm{SeO}_{3}{ }^{2-}$ concentration was increased in $10 \mathrm{mM}$ increments. After $24 \mathrm{~h}$ of incubation at $30{ }^{\circ} \mathrm{C}$, aliquots $(100 \mu \mathrm{L})$ of the cells in each treatment were spotted onto YEP agar plates and incubated for a further $24 \mathrm{~h}$ at $30{ }^{\circ} \mathrm{C}$ to determine the concentrations of $\mathrm{SeO}_{3}{ }^{2-}$ that inhibited bacterial growth.

\subsection{Evaluation of the Reduction Efficiency of Se03}

The reduction efficiency of the Se03 isolate was investigated by adding it to a $500 \mathrm{~mL}$ flask containing $200 \mathrm{~mL}$ of YEP medium and Na2SeO3 $(1 \mathrm{mM}$ or $5 \mathrm{mM})$ and culturing it at $30^{\circ} \mathrm{C}$ in a rotary shaker incubator (180 rpm).

\subsubsection{Evaluation of Bacterial Growth Dynamics after Exposure to $\mathrm{SeO}_{3}{ }^{2-}$}

The growth dynamics of the Se03 isolate was investigated by sampling $10 \mathrm{~mL}$ of Se03 culture every $6 \mathrm{~h}$ from each flask to determine the $\mathrm{SeO}_{3}{ }^{2-}$ reduction efficiency and $\mathrm{Se}^{0}$ levels. At the same time, $100 \mu \mathrm{L}$ of Se03 culture was sampled every $6 \mathrm{~h}$, serially diluted with sterile $\mathrm{ddH}_{2} \mathrm{O}$, spotted onto YEP 
agar plates, and incubated at $30^{\circ} \mathrm{C}$ for $24 \mathrm{~h}$. The number of growing cells was counted and reported as the average $(n=3)$ and standard deviation of colony forming units per milliliter (CFU/mL).

\subsubsection{Assessment of $\mathrm{SeO}_{3}{ }^{2-}$ Bio-Reduction Efficiency}

Inductively coupled plasma optical emission spectrometry (ICP-OES) (Thermo Fischer Scientific, Waltham, MA, USA) was employed to determine the selenite concentration in each sample as described by Nawaz et al. [59] with slight modifications. Briefly, $10 \mathrm{~mL}$ of bacterial culture was sampled every $6 \mathrm{~h}$ from each culture, followed by centrifugation at 12,000 $\mathrm{g}$ for $20 \mathrm{~min}$. After centrifugation, the bacterial cells and elemental selenium were collected as a pellet for subsequent $\mathrm{Se}^{0}$ content analysis. The supernatant was passed through a $0.22 \mu \mathrm{m}$ filter. After that, $300 \mu \mathrm{L}$ of the supernatant was mixed with $3 \mathrm{~mL}$ of $\mathrm{HNO}_{3}$, left overnight, and passed through the $0.22 \mu \mathrm{m}$ filter again. The samples were then diluted to the appropriate selenium concentration and subjected to ICP-OES analysis.

\subsection{3. $\mathrm{Se}^{0}$ Content Analysis}

$\mathrm{Se}^{0}$ concentration was determined using the spectrophotometric method described by Khoei et al. [10] with minor modifications. First, the intensity of red $\mathrm{Se}^{0}$ produced by reducing selenite solutions of 1-10 $\mu \mathrm{mol}$ with $25 \mu \mathrm{mol} \mathrm{HN} \mathrm{HN}_{2} \mathrm{OH} \cdot \mathrm{HCl}$ was measured at a wavelength of $490 \mathrm{~nm}$ to establish a calibration curve. The pellets from the previous centrifugation step were first washed three times with $10 \mathrm{~mL}$ of $1 \mathrm{M} \mathrm{NaCl}$ to remove selenite contamination, followed by sonication as described by Khoei et al. [10]. After sonication, the pellets were washed twice with $10 \mathrm{~mL}$ of $1 \mathrm{M} \mathrm{NaCl}$ and dissolved in $10 \mathrm{~mL}$ of $1 \mathrm{M} \mathrm{Na}_{2} \mathrm{~S}$. Finally, the samples were centrifuged at $8000 \times g$ for $20 \mathrm{~min}$ to separate the cells, and the absorption of the supernatant (the reddish solution) was measured using spectrophotometry at $490 \mathrm{~nm}$.

\subsection{Location of SeNPs within the Bacterial Cells}

The location of SeNPs within the bacterial cells was determined using TEM and SEM analysis of the bacterial cultures grown either in the YEP medium only (control) or in the YEP medium to which $5.0 \mathrm{mM} \mathrm{Na}_{2} \mathrm{SeO}_{3}$ had been added.

\subsubsection{TEM Analysis}

The bacterial cultures grown in both the control and in the YEP/ $\mathrm{Na}_{2} \mathrm{SeO}_{3}$ mixture were collected after $36 \mathrm{~h}$ of incubation at $30^{\circ} \mathrm{C}$. The cells were harvested using centrifugation at $5000 \times g$ for $6 \mathrm{~min}$ and fixed with $2 \%$ glutaraldehyde in $0.1 \mathrm{M}$ phosphate-buffered saline (PBS, $\mathrm{pH} 7.4$ ) for $2 \mathrm{~h}$. The cells then underwent post-fixation treatment in $1 \%$ osmium tetroxide for $2 \mathrm{~h}$. The samples were subsequently processed using standard procedures and mounted on copper grids. The analysis was conducted at $80 \mathrm{kV}$ with a Hitachi HT-7700 (Tokyo, Japan) transmission electron microscope.

\subsubsection{SEM Analysis}

The bacterial cultures grown in the control and in the $\mathrm{YEP} / \mathrm{Na}_{2} \mathrm{SeO}_{3}$ mixture were collected after $36 \mathrm{~h}$ incubation at $30{ }^{\circ} \mathrm{C}$. The cells were harvested using centrifugation at $5000 \times g$ for $5 \mathrm{~min}$ and fixed overnight in $2.5 \%$ glutaraldehyde at $4{ }^{\circ} \mathrm{C}$. Following this, the cells were washed twice in PBS (0.1 M, pH 7.4) and dehydrated using an ethanol series (30\%,50\%,70\%,80\%, 90\%, and 100\%). Finally, they were dried using the critical point drying method with $\mathrm{CO}_{2}$ and analyzed with an $\mathrm{S} 4800$ (Tokyo, Japan) scanning electron microscope.

\subsection{Analysis of SeNPs}

\subsubsection{Preparation of Biogenic SeNPs}

The Se03 isolate was cultured in 500-mL flasks containing $200 \mathrm{~mL}$ of YEP medium and $5 \mathrm{mM} \mathrm{Na}_{2} \mathrm{SeO}_{3}$ at $30{ }^{\circ} \mathrm{C}$ in a rotary shaker $(180 \mathrm{rpm})$ for $36 \mathrm{~h}$. After incubation, the bacterial culture was centrifuged at 
$10,000 \times g$ at $4{ }^{\circ} \mathrm{C}$ for $10 \mathrm{~min}$. The pellet was collected and rinsed twice with $0.9 \% \mathrm{NaCl}$. After this, the pellet was resuspended in $20 \mathrm{~mL}$ of Tris- $\mathrm{Cl}$ buffer $(50 \mathrm{mM}, \mathrm{pH} 8.2)$ and disrupted by ultra-sonication on ice (ten cycles of $40 \mathrm{~s}$ of sonication with $40 \mathrm{~s}$ of rest). After sonication, the suspension was centrifuged at $12,000 \times$ $g$ for $40 \mathrm{~min}$. The pellet was discarded while the supernatant was centrifuged at $40,000 \times g$ at $4{ }^{\circ} \mathrm{C}$ for 40 min to harvest the nanoparticles. Finally, the subsequent pellet containing the SeNPs was washed twice with water and then resuspended in deionized water.

\subsubsection{Dynamic Light Scattering (DLS) Analysis}

DLS analysis was conducted using a Zen 3600 Zetasizer Nano ZS from Malvern Instruments Ltd. (Worcestershire, UK) equipped with a 633-nm helium-neon laser light source $(4.0 \mathrm{~mW})$. Before the measurement, the SeNPs suspensions were diluted to 1:10 to 1:20 to meet the optical requirements of the instrument, and the mean size distribution of the selenium particles was determined as described by Lampis et al. [29].

\subsubsection{Scanning Electron Microscopy and Electron Dispersive Spectrometry (SEM-EDS) Analysis}

The morphology and constituent elements of the purified SeNPs were analyzed using SEM-EDS analysis. For this purpose, the SeNPs suspensions were first dried with a vacuum freeze dryer (SJIA-10N, Ningbo YinZhou Sjia Lab Equipment Co., Ltd., YinZhou, China) and the selenium particles were then analyzed with a scanning electron microscope (Hitachi S4800, Tokyo, Japan) with energy-dispersive X-ray spectra (SEM-EDS).

\subsubsection{Fourier Transform Infrared (FTIR) Spectroscopy Analysis}

For the FTIR analysis, the SeNP suspensions were first dried with a vacuum freeze dryer (SJIA-10N, Ningbo YinZhou Sjia Lab Equipment Co., Ltd., YinZhou, China). Mid-infrared spectroscopy $\left(4000-400 \mathrm{~cm}^{-1}\right.$ ) was applied in transmission mode employing a Nicolet IS10 spectrometer (Thermo Fischer Scientific, Waltham, MA, USA).

\subsection{Biocatalytic Selenite Reduction Assays}

To demonstrate which fractions of the cell culture (the cytoplasm, periplasm, membrane, and exopolysaccharide [EPS] fractions, and the culture supernatant) were responsible for selenite reduction and SeNPs formation, and to clarify the possible reduction mechanisms, the biocatalytic reduction of selenite was assessed with the different fractions of Se03.

\subsubsection{Protein Extraction}

To extract the cell protein fractions, Se03 was cultured in 1-L flasks containing $400 \mathrm{~mL}$ of YEP medium at $30^{\circ} \mathrm{C}$ in a rotary shaker $(180 \mathrm{rpm})$ for $20 \mathrm{~h}$. The bacterial culture was then centrifuged at $10,000 \times g$ at $4^{\circ} \mathrm{C}$ for $10 \mathrm{~min}$ to collect the cell pellet. Following this, the pellet was washed twice with $0.9 \% \mathrm{NaCl}$ and pelleted again. The periplasmic, membrane, fractions and soluble cytoplasmic fractions were then extracted following the process described by Khoei et al. [10]. In addition, the protein content of the individual fractions was determined using Bradford assays with bovine serum albumin as the standard.

\subsubsection{EPS Extraction}

To extract the EPS fraction, $100 \mathrm{~mL}$ of the Se 03 culture incubated in YEP at $30{ }^{\circ} \mathrm{C}$ for $5 \mathrm{~d}$ was centrifuged at $12,000 \times g$ at $4{ }^{\circ} \mathrm{C}$ for $30 \mathrm{~min}$ and the pellet was discarded. The supernatant was then passed through a $0.22 \mu \mathrm{m}$ filter and precipitated with an equal volume of cold ethanol at $-20^{\circ} \mathrm{C}$ overnight. Following this, the pellet containing the EPS fraction was harvested using centrifugation at $12,000 \times g$ for $30 \mathrm{~min}$ at $4{ }^{\circ} \mathrm{C}$ and dissolved in sterile $\mathrm{ddH}_{2} \mathrm{O}$. 


\subsubsection{Supernatant Preparation}

Stationary phase cultures (incubated for $24 \mathrm{~h}$ ) of Se03 in YEP were centrifuged at $10,000 \times g$ for $5 \mathrm{~min}$ at $4{ }^{\circ} \mathrm{C}$. The supernatant was passed through a $0.22 \mu \mathrm{m}$ filter and collected.

\subsubsection{Selenite Reducing Reduction Activity Assays}

The selenite reduction activity of the individual fractions of the bacterial cultures was assessed as described by Khoei et al. [10] with minor modifications. Generally, the appearance of a red color in the microplate wells indicated the production of elemental selenium.

The activity assays were performed in 96-well plates. First, $100 \mu \mathrm{L}$ of the protein $(2 \mathrm{mg} / \mathrm{mL})$, EPS, or supernatant samples was carefully transferred into the 96-well plate. Subsequently, $88 \mu \mathrm{L}$ of Mcllvaine buffer, $10 \mu \mathrm{L}$ of sodium selenite solution (a final concentration of $5.0 \mathrm{mM}$ ), and $2 \mu \mathrm{L}$ of NADH (electron donor, final concentration $2.0 \mathrm{mM}$ ) were added to each well to obtain a final volume of $200 \mu \mathrm{L}$. Afterwards, the mixture was incubated at $30{ }^{\circ} \mathrm{C}$ for at least $72 \mathrm{~h}$. The experiment was repeated with NADPH as an alternative electron donor). Three negative controls were set: Without selenite, without an electron donor, and without the cell protein/EPS/supernatant. The presence of red in the wells, indicating the production of elemental selenium, was interpreted as a positive result.

\subsection{Real-Time Quantitative PCR ( $q P C R)$}

To determine the proteins that might be involved in the reduction of $\mathrm{SeO}_{3}{ }^{2-}$ to SeNPs, the mRNA expression of various enzymes, including sulfite reductase (cysI) and flavoprotein sulfite reductase (BV899_18870), in response to selenite treatment were assessed using qPCR. The gene-specific primers are presented in Table 2 with the $16 \mathrm{~S}$ rRNA gene sequence as a reference.

Bacterial cultures grown in YEP medium (control) or in YEP medium to which $5.0 \mathrm{mM} \mathrm{Na}_{2} \mathrm{SeO}_{3}$ had been added were collected after $24 \mathrm{~h}$ of incubation at $30^{\circ} \mathrm{C}$. After incubation, total bacterial RNA was extracted from $2 \mathrm{~mL}$ of bacterial culture using an E.Z.N.A. bacterial RNA kit (Omega Bio-tek, USA) following the manufacturer's protocol, and the RNA concentration was determined using a ScanDrop spectrophotometer (Analytik Jena AG, Jena, Germany). cDNA was then synthesized using TransScript One-Step gDNA Removal and cDNA Synthesis SuperMix (TransGen Biotech, Peking, China). Afterwards, the cDNA was subjected to qPCR analysis using a QuantiFast SYBR Green PCR kit (Qiagen, Germany) on a Roche LC96 real-time PCR machine (Roche Diagnostics, Indianapolis, IN, USA). The qPCR process was as follows: One cycle at $95^{\circ} \mathrm{C}$ for $10 \mathrm{~min}$, followed by 45 cycles at $95^{\circ} \mathrm{C}$ for $10 \mathrm{~s}, 55^{\circ} \mathrm{C}$ for $20 \mathrm{~s}$, and $72{ }^{\circ} \mathrm{C}$ for $20 \mathrm{~s}$. Melting curve analysis was performed moving from $60{ }^{\circ} \mathrm{C}$ to $95^{\circ} \mathrm{C}$ by $0.5^{\circ} \mathrm{C}$ every $2 \mathrm{~s}$. Variation in gene expression was evaluated in terms of the change with respect to the untreated cells (control) using the $2^{-\Delta \Delta C t}$ method. Each sample was tested three times and three independent tests were conducted.

\subsection{Statistical Analysis}

Normality of continuous data was determined by Shapiro-Wilk normality test. One-way analysis of variance (ANOVA) at a 95\% confidence level followed by Tukey's test was used to determine the statistical significance of pairwise comparisons. All analyses were conducted in triplicate, and all values presented are the average of three independent sets and expressed as the mean \pm standard deviation (S.D.). The level of significance was set at $p<0.05$.

\section{Conclusions}

In summary, the bacterium strain A. faecalis Se03, which has a high selenite tolerance and a strong reduction ability, was isolated from the gut of $M$. alternatus larvae. To the best of our knowledge, this is the first study to demonstrate that $A$. faecalis is capable of efficiently transforming toxic $\mathrm{SeO}_{3}{ }^{2-}$ to $\mathrm{Se}^{0}$ and generating SeNPs in a liquid growth medium under aerobic growth conditions. The in vitro synthesis experimental results indicated that SeNP formation can be tentatively attributed 
to cytoplasmic enzymatic activation mediated by electron donors (NADPH or NADH). However, intracellular elemental selenium was also observed, even though the SeNPs were primarily located in the extracellular space. Therefore, it is likely that the biogenic SeNPs were released outside the bacterial cells as a consequence of a secretory process or cell lysis. Further studies are needed in order to clarify the specific mechanisms of SeNP synthesis and how these particles are transported out of cells.

Supplementary Materials: Supplementary materials can be found at http:/ /www.mdpi.com/1422-0067/19/9/2799/s1.

Author Contributions: Conceptualization, S.H. and L.W.; Methodology, Y.W., S.H. and L.W.; Software, X.S. and Q.Z.; Validation, Y.W., S.H.; Formal Analysis, T.F. and T.W.; Investigation, Y.W. and X.C.; Resources, M.L.; Data Curation, Y.M., J.N., J.H.; Writing-Original Draft Preparation, S.H. and L.W.; Writing-Review \& Editing, W.Z. and R.L.; Supervision, L.W.

Funding: This study was funded by the National Natural Science Foundation of China (31500531), the Science and Technology Service Program of the Chinese Academy of Sciences (KFJ-STS-ZDTP-002), the key program of 13th five-year plan, CASHIPS (No. kp-2017-21), the Grant of the President Foundation of the Hefei Institutes of Physical Science of the Chinese Academy of Sciences (YZJJ201619), the major special project of Anhui Province (16030701103) and the Natural Science Foundation of Anhui Province (1708085QC70), Scientific and Technological Innovation Team of Anhui Academy of Agricultural Sciences(18C0614), Hefei Comprehensive Experimental Station of National Sericultural Industry's Technological System (CARS-18-SYZ07).

Conflicts of Interest: The authors declare no conflict of interest.

$\begin{array}{ll}\text { Abbreviations } \\ \text { SeNPs } & \text { Se nanoparticles } \\ \mathrm{Se}^{0} & \text { Elemental Selenium } \\ \mathrm{TEM} & \text { Transmission electron microscopy } \\ \text { SEM } & \text { Scanning electron microscopy } \\ \text { EDX } & \text { Energy dispersive X-ray analysis } \\ \text { MIC } & \text { Minimum inhibitory concentration } \\ \text { NADH } & \text { Nicotinamide adenine dinucleotide } \\ \text { NADPH } & \text { Nicotinamide adenine dinucleotide phosphate } \\ \text { qPCR } & \text { Real-time quantitative PCR }\end{array}$

\section{References}

1. Hunter, W.J. Pseudomonas seleniipraecipitans proteins potentially involved in selenite reduction. Curr. Microbiol. 2014, 69, 69-74. [CrossRef] [PubMed]

2. Kessi, J.; Ramuz, M.; Wehrli, E.; Spycher, M.; Bachofen, R. Reduction of selenite and detoxification of elemental selenium by the phototrophic bacterium Rhodospirillum rubrum. Appl. Environ. Microbiol. 1999, 65, 4734-4740. [PubMed]

3. Bajaj, M.; Schmidt, S.; Winter, J. Formation of se ${ }^{(0)}$ nanoparticles by Duganella sp. And Agrobacterium sp. Isolated from se-laden soil of north-east punjab, india. Microb. Cell Fact. 2012, 11, 64. [CrossRef] [PubMed]

4. Nguyen, V.K.; Park, Y.; Yu, J.; Lee, T. Microbial selenite reduction with organic carbon and electrode as sole electron donor by a bacterium isolated from domestic wastewater. Bioresource. Technol. 2016, 212, $182-189$. [CrossRef] [PubMed]

5. Whanger, P.D. Selenocompounds in plants and animals and their biological significance. J. Am. Coll. Nutr. 2002, 21, 223-232. [CrossRef] [PubMed]

6. Sors, T.G.; Ellis, D.R.; Salt, D.E. Selenium uptake, translocation, assimilation and metabolic fate in plants. Photosynth. Res. 2005, 86, 373-389. [CrossRef] [PubMed]

7. Nancharaiah, Y.V.; Lens, P.N.L. Selenium biomineralization for biotechnological applications. Trends Biotechnol. 2015, 33, 323-330. [CrossRef] [PubMed]

8. Nishimura, T.; Hashimoto, H.; Nakayama, M. Removal of selenium(vi) from aqueous solution with polyamine-type weakly basic ion exchange resin. Sep. Sci. Technol. 2007, 42, 3155-3167. [CrossRef]

9. Chung, J.; Nerenberg, R.; Rittmann, B.E. Bioreduction of selenate using a hydrogen-based membrane biofilm reactor. Environ. Sci. Technol. 2006, 40, 1664-1671. [CrossRef] [PubMed] 
10. Khoei, N.S.; Lampis, S.; Zonaro, E.; Yrjälä, K.; Bernardi, P.; Vallini, G. Insights into selenite reduction and biogenesis of elemental selenium nanoparticles by two environmental isolates of Burkholderia fungorum. New Biotechnol. 2017, 34, 1-11. [CrossRef] [PubMed]

11. Yee, N.; Ma, J.; Dalia, A.; Boonfueng, T.; Kobayashi, D. Se(VI) reduction and the precipitation of se ${ }^{(0)}$ by the facultative bacterium Enterobacter cloacae SLD1a-1 are regulated by FNR. Appl. Environ. Microbiol. 2007, 73, 1914-1920. [CrossRef] [PubMed]

12. Fernández-Llamosas, H.; Castro, L.; Blázquez, M.L.; Díaz, E.; Carmona, M. Speeding up bioproduction of selenium nanoparticles by using Vibrio natriegens as microbial factory. Sci. Rep. 2017, 7, 16046. [CrossRef] [PubMed]

13. Avendaño, R.; Chaves, N.; Fuentes, P.; Sánchez, E.; Jiménez, J.I.; Chavarría, M. Production of selenium nanoparticles in Pseudomonas putida kt2440. Sci. Rep. 2016, 6, 37155. [CrossRef] [PubMed]

14. Dhanjal, S.; Cameotra, S.S. Aerobic biogenesis of selenium nanospheres by Bacillus cereus isolated from coalmine soil. Microb. Cell Fact. 2010, 9, 52. [CrossRef] [PubMed]

15. Lampis, S.; Zonaro, E.; Bertolini, C.; Bernardi, P.; Butler, C.S.; Vallini, G. Delayed formation of zero-valent selenium nanoparticles by Bacillus mycoides SelTE01 as a consequence of selenite reduction under aerobic conditions. Microb. Cell Fact. 2014, 13, 35. [CrossRef] [PubMed]

16. Li, D.B.; Cheng, Y.Y.; Wu, C.; Li, W.W.; Li, N.; Yang, Z.C.; Tong, Z.H.; Yu, H.Q. Selenite reduction by Shewanella oneidensis MR-1 is mediated by fumarate reductase in periplasm. Sci. Rep. 2014, 4, 3735. [CrossRef] [PubMed]

17. Kieliszek, M.; Błażejak, S.; Gientka, I.; Bzducha-Wróbel, A. Accumulation and metabolism of selenium by yeast cells. Appl. Microbiol. Biotechnol. 2015, 99, 5373-5382. [CrossRef] [PubMed]

18. Jiménez-lamana, J.; Abadálvaro, I.; Bierla, K.; Laborda, F.; Szpunar, J.; Lobinski, R. Detection and characterization of biogenic selenium nanoparticles in selenium-rich yeast by single particle ICPMS. J. Anal. At. Spectrom. 2018, 33, 452-460. [CrossRef]

19. Fernández-Llamosas, H.; Castro, L.; Blázquez, M.L.; Díaz, E.; Carmona, M. Biosynthesis of selenium nanoparticles by Azoarcus sp. CIB. Microb. Cell Fact. 2016, 15, 109. [CrossRef] [PubMed]

20. Wadhwani, S.A.; Shedbalkar, U.U.; Singh, R.; Chopade, B.A. Biogenic selenium nanoparticles: Current status and future prospects. Appl. Microbiol. Biotechnol. 2016, 100, 2555-2566. [CrossRef] [PubMed]

21. Zhang, W.; Chen, Z.; Liu, H.; Zhang, L.; Gao, P.; Li, D. Biosynthesis and structural characteristics of selenium nanoparticles by Pseudomonas alcaliphila. Colloids Surf. B Biointerfaces 2011, 88, 196-201. [CrossRef] [PubMed]

22. Che, L.; Dong, Y.; Wu, M.; Zhao, Y.; Liu, L.; Zhou, H. Characterization of selenite reduction by Lysinibacillus sp. ZYM-1 and photocatalytic performance of biogenic selenium nanospheres. ACS Sustain. Chem. Eng. 2017, 5, 2535-2543. [CrossRef]

23. Ramamurthy, C.; Sampath, K.S.; Arunkumar, P.; Kumar, M.S.; Sujatha, V.; Premkumar, K.; Thirunavukkarasu, C. Green synthesis and characterization of selenium nanoparticles and its augmented cytotoxicity with doxorubicin on cancer cells. Bioprocess Biosyst. Eng. 2013, 36, 1131-1139. [CrossRef] [PubMed]

24. Bhattacharjee, A.; Basu, A.; Sen, T.; Biswas, J.; Bhattacharya, S. Nano-se as a novel candidate in the management of oxidative stress related disorders and cancer. Nucleus 2017, 60, 137-145. [CrossRef]

25. Srivastava, P.; Braganca, J.M.; Kowshik, M. In vivo synthesis of selenium nanoparticles by Halococcus salifodinae bk18 and their anti-proliferative properties against hela cell line. Biotechnol. Prog. 2014, 30, 1480-1487. [CrossRef] [PubMed]

26. Joo, H.-S.; Hirai, M.; Shoda, M. Characteristics of ammonium removal by heterotrophic nitrification-aerobic denitrification by Alcaligenes faecalis no. 4. J. Biosci. Bioeng. 2005, 100, 184-191. [CrossRef] [PubMed]

27. Singha, L.P.; Kotoky, R.; Pandey, P. Draft genome sequence of Alcaligenes faecalis BDB4, a polyaromatic hydrocarbon-degrading bacterium isolated from crude oil-contaminated soil. Genome Announc. 2017, 5, e01346-17. [CrossRef] [PubMed]

28. Tan, Y.; Rong, Y.; Rui, W.; Dan, W.; Wang, G.; Zheng, S. Reduction of selenite to Se ${ }^{(0)}$ nanoparticles by filamentous bacterium Streptomyces sp. ES2-5 isolated from a selenium mining soil. Microb. Cell Fact. 2016, 15, 157. [CrossRef] [PubMed]

29. Lampis, S.; Zonaro, E.; Bertolini, C.; Cecconi, D.; Monti, F.; Micaroni, M.; Turner, R.J.; Butler, C.S.; Vallini, G. Selenite biotransformation and detoxification by Stenotrophomonas maltophilia SelTE02: Novel clues on the route to bacterial biogenesis of selenium nanoparticles. J. Hazard. Mater. 2017, 324, 3-14. [CrossRef] [PubMed] 
30. Huang, S.W.; Zhang, H.Y.; Marshall, S.; Jackson, T.A. The scarab gut: A potential bioreactor for bio-fuel production. Insect Sci. 2010, 17, 175-183. [CrossRef]

31. Undugoda, L.J.S.; Kannangara, S.; Sirisena, D.M. Genetic basis of naphthalene and phenanthrene degradation by phyllosphere bacterial strains Alcaligenes faecalis and Alcaligenes sp. 11SO. J. Bioremediat. Biodegrad. 2016, 7, 2.

32. Silver, S.; Phung, L.T. Genes and enzymes involved in bacterial oxidation and reduction of inorganic arsenic. Appl. Environ. Microbiol. 2005, 71, 599-608. [CrossRef] [PubMed]

33. Shakoori, F.R.; Tabassum, S.; Rehman, A.; Shakoori, A.R. Isolation and characterization of $\mathrm{Cr}^{6+}$ reducing $^{\mathrm{s}}$ bacteria and their potential use in bioremediation of chromium containing wastewater. Pak. J. Zool. 2010, 42, 651-658.

34. Staicu, L.C.; Ackerson, C.J.; Cornelis, P.; Ye, L.; Berendsen, R.L.; Hunter, W.J.; Noblitt, S.D.; Henry, C.S.; Cappa, J.J.; Montenieri, R.L. Pseudomonas moraviensis subsp. Stanleyae, a bacterial endophyte of hyperaccumulator stanleya pinnata, is capable of efficient selenite reduction to elemental selenium under aerobic conditions. J. Appl. Microbiol. 2015, 119, 400-410. [CrossRef] [PubMed]

35. Van Fleet-Stalder, V.; Chasteen, T.G.; Pickering, I.J.; George, G.N.; Prince, R.C. Fate of selenate and selenite metabolized by Rhodobacter sphaeroides. Appl. Environ. Microbiol. 2000, 66, 4849-4853. [CrossRef] [PubMed]

36. Kieliszek, M.; Błażejak, S.; Bzducha-Wróbel, A.; Kurcz, A. Effects of selenium on morphological changes in Candida utilis atcc 9950 yeast cells. Biol. Trace Element Res. 2016, 169, 387-393. [CrossRef] [PubMed]

37. Switzer, B.J.; Burns, B.A.; Buzzelli, J.; Stolz, J.F.; Oremland, R.S. Bacillus arsenicoselenatis, sp. nov. and Bacillus selenitireducens, sp. nov.: two haloalkaliphiles, from Mono Lake, California that respire oxyanions, of selenium and arsenic. Arch. Microbiol. 1998, 171, 19-30. [CrossRef]

38. Debieux, C.M.; Dridge, E.J.; Mueller, C.M.; Splatt, P.; Paszkiewicz, K.; Knight, I.; Florance, H.; Love, J.; Titball, R.W.; Lewis, R.J.; et al. A bacterial process for selenium nanosphere assembly. Proc. Natl. Acad. Sci. USA 2011, 108, 13480-13485. [CrossRef] [PubMed]

39. Hunter, W.J. A rhizobium selenitireducens protein showing selenite reductase activity. Curr. Microbiol. 2014, 68, 311-316. [CrossRef] [PubMed]

40. Xia, X.; Wu, S.; Li, N.; Wang, D.; Zheng, S.; Wang, G. Novel bacterial selenite reductase csrf responsible for se(iv) and cr(vi) reduction that produces nanoparticles in Alishewanella sp. WH16-1. J. Hazard. Mater. 2018, 342, 499-509. [CrossRef] [PubMed]

41. Kulp, A.; Kuehn, M.J. Biological functions and biogenesis of secreted bacterial outer membrane vesicles. Annu. Rev. Microbiol. 2010, 64, 163-184. [CrossRef] [PubMed]

42. Pearce, C.I.; Coker, V.S.; Charnock, J.M.; Pattrick, R.A.; Mosselmans, J.F.; Law, N.; Beveridge, T.J.; Lloyd, J.R. Microbial manufacture of chalcogenide-based nanoparticles via the reduction of selenite using Veillonella atypica: An in situ EXAFS study. Nanotechnology 2008, 19, 155603. [CrossRef] [PubMed]

43. Nancharaiah, Y.V.; Lens, P.N.L. Ecology and biotechnology of selenium-respiring bacteria. Microbiol. Mol. Biol. Rev. 2015, 79, 61-80. [CrossRef] [PubMed]

44. Staicu, L.C.; Barton, L.L. Bacterial metabolism of selenium-for survival or profit. In Bioremediation of Selenium Contaminated Wastewater; Van Hullebusch, E., Ed.; Spinger: Cham, Switzerland; Heidelberg, Germany, 2017; pp. 1-31.

45. Tomei, F.A.; Barton, L.L.; Lemanski, C.L.; Zocco, T.G.; Fink, N.H.; Sillerud, L.O. Transformation of selenate and selenite to elemental selenium by Desulfovibrio desulfuricans. J. Industr. Microbiol. 1995, 14, 329-336. [CrossRef]

46. Song, D.; Li, X.; Cheng, Y.; Xiao, X.; Lu, Z.; Wang, Y.; Wang, F. Aerobic biogenesis of selenium nanoparticles by Enterobacter cloacae Z0206 as a consequence of fumarate reductase mediated selenite reduction. Sci. Rep. 2017, 7, 3239. [CrossRef] [PubMed]

47. Tugarova, A.V.; Kamnev, A.A. Proteins in microbial synthesis of selenium nanoparticles. Talanta 2017, 174, 539-547. [CrossRef] [PubMed]

48. Mapelli, V.; Hillestrøm, P.R.; Patil, K.; Larsen, E.H.; Olsson, L. The interplay between sulphur and selenium metabolism influences the intracellular redox balance in Saccharomyces cerevisiae. FEMS Yeast Res. 2012, 12, 20-32. [CrossRef] [PubMed]

49. Tetteh, A.Y.; Sun, K.H.; Hung, C.Y.; Kittur, F.S.; Ibeanu, G.C.; Williams, D.; Xie, J. Transcriptional response of selenopolypeptide genes and selenocysteine biosynthesis machinery genes in Escherichia coli during selenite reduction. Int. J. Microbiol. 2014, 394835. 
50. Sarret, G.; Avoscan, L.; Carrière, M.; Collins, R.; Geoffroy, N.; Carrot, F.; Covès, J.; Gouget, B. Chemical forms of selenium in the metal-resistant bacterium Ralstonia metallidurans $\mathrm{CH} 34$ exposed to selenite and selenate. Appl. Environ. Microbiol. 2005, 71, 2331-2337. [CrossRef] [PubMed]

51. Harrison, G.; Curle, C.; Laishley, E.J. Purification and characterization of an inducible dissimilatory type sulfite reductase from Clostridium pasteurianum. Arch. Microbiol. 1984, 138, 72-78. [CrossRef] [PubMed]

52. Kumar, S.; Björnstedt, M.; Holmgren, A. Selenite is a substrate for calf thymus thioredoxin reductase and thioredoxin and elicits a large non-stoichiometric oxidation of NADPH in the presence of oxygen. Eur. J. Biochem. 2010, 207, 435-439. [CrossRef]

53. Bébien, M.; Lagniel, G.; Garin, J.; Touati, D.; Verméglio, A.; Labarre, J. Involvement of superoxide dismutases in the response of Escherichia coli to selenium oxides. J. Bacteriol. 2002, 184, 1556-1564. [CrossRef] [PubMed]

54. Lenz, M.; Kolvenbach, B.; Gygax, B.; Moes, S.; Corvini, P.F. Shedding light on selenium biomineralization: Proteins associated with bionanominerals. Appl. Environ. Microbiol. 2011, 77, 4676-4680. [CrossRef] [PubMed]

55. Huang, S.; Sheng, P.; Zhang, H. Isolation and identification of cellulolytic bacteria from the gut of Holotrichia parallela larvae (coleoptera: Scarabaeidae). Int. J. Mol. Sci. 2012, 13, 2563-2577. [CrossRef] [PubMed]

56. Holt, J.G.; Krieg, N.R.; Snealth, P.H.A.; Staley, J.T.; Williams, S.T. Bergey's Manual of Determinative Bacteriology, 9th ed.; Lippincott Williams \& Wilkins: Baltimore, MD, USA, 2000; pp. 175-289.

57. Yoon, S.H.; Ha, S.M.; Kwon, S.; Lim, J.; Kim, Y.; Seo, H.; Chun, J. Introducing ezbiocloud: A taxonomically united database of 16s rRNA gene sequences and whole-genome assemblies. Int. J. Syst. Evol. Microbiol. 2017, 67, 1613-1617. [PubMed]

58. Kumar, S.; Stecher, G.; Tamura, K. Mega7: Molecular evolutionary genetics analysis version 7.0 for bigger datasets. Mol. Biol. Evol. 2016, 33, 1870-1874. [CrossRef] [PubMed]

59. Nawaz, F.; Ahmad, R.; Ashraf, M.Y.; Waraich, E.A.; Khan, S.Z. Effect of selenium foliar spray on physiological and biochemical processes and chemical constituents of wheat under drought stress. Ecotoxicol. Environ. Saf. 2015, 113, 191-200. [CrossRef] [PubMed] 